\title{
Attack on the Humanities and Social Sciences in Brazil
}

\author{
Interview with Sidney Chalhoub, Marine \\ Corde and Angela Facundo Navia
}

Céline Mavrot and Romain Tiquet

\section{Avertissement}

Le contenu de ce site relève de la législation belge sur la propriété intellectuelle et est la propriété exclusive de l'éditeur.

Les œuvres figurant sur ce site peuvent être consultées et reproduites sur un support papier ou numérique sous réserve qu'elles soient strictement réservées à un usage soit personnel, soit scientifique ou pédagogique excluant toute exploitation commerciale. La reproduction devra obligatoirement mentionner l'éditeur, le nom de la revue, l'auteur et la référence du document.

Toute autre reproduction est interdite sauf accord préalable de l'éditeur, en dehors des cas prévus par la législation en vigueur en Belgique.

\section{Référence électronique}

Citation : Sidney Chalhoub, Marine Corde, Angela Facundo Navia, Céline Mavrot, Romain Tiquet « Current Situation Attack on the Humanities and Social Sciences in Brazil. Interview with Sidney Chalhoub, Marine Corde and Angela Facundo Navia » Emulations, en ligne. Mise en ligne le 21 avril 2020.

URL : https://ojs.uclouvain.be/index.php/emulations/article/view/chalhoubetal

Éditeur : Émulations. Revue de sciences sociales http://www.revue-emulations.net 


\title{
Current Situation
}

\section{Attack on the Humanities and Social Sciences in Brazil}

\author{
Interview with Sidney Chalhoub, \\ Marine Corde and Angela Facundo Navia
}

Céline Mavrot and Romain Tiquet

Dans le cadre des attaques récentes du président Jair Bolsonaro à l'encontre de la philosophie et de la sociologie au sein du système d'éducation supérieure, Émulations reçoit trois spécialistes - Sidney Chalhoub, Marine Corde, Angela Facundo Navia - pour un entretien croisé sur la situation des sciences humaines et sociales au Brésil à la lumière de l'actualité politique du pays. Cet entretien a été réalisé par Céline Mavrot et Romain Tiquet.

In the wake of President Jair Bolsonaro's recent attacks on philosophy and sociology in the higher education system, Émulations is pleased to welcome three experts for a cross-interview on the situation of human and social sciences in Brazil in light of the current political situation. This interview was conducted by Céline Mavrot and Romain Tiquet.

Sidney Chalhoub is a professor of history and of African and African American studies at Harvard University. Before that, he taught for thirty years in Brazil (University of Campinas). His research draws on social history and focuses on racialism, power relationships within Brazilian society, slavery, and public health. Some of his recent work includes: "The Legacy of Slavery: Tales of Gender and Racial Violence in Machado de Assis", in Lamonte Aidoo and Daniel F. Silva, eds., Emerging Dialogues on Machado de Assis (2016) and "The Politics of Ambiguity: Conditional Manumission, Labor Contracts and Slave Emancipation in Brazil (1850s to 1888)" (International Review of Social History, 60, 2015).

Marine Corde is a post-doctoral researcher in anthropology. She holds a Ph.D. from the Museu Nacional/Federal University of Rio de Janeiro and carried out research and teaching for five years in various Brazilian universities. Her research focus is on anti-discrimination campaigns in partnership with governmental and non-governmental organizations. Her recent research comprises: « Mémoires d'immigrés, mémoires de France ? Mémoires et reconnaissance » (Conserveries mémorielles, 13, 2013) and "A articulação entre objetividade e subjetividade nos textos antropológicos: contribuições da escrita literária para a construção de saberes antropológicos” (Revista de Ciências Sociais, 44-2, 2013).

Angela Facundo Navia is a professor of anthropology at the Federal University of Rio Grande del Norte and the President of the northeast region of the Brazilian Association of Anthropology. Her research explores the racialized and gendered boundaries of nation, the states' practices of governance regarding refugees and the processes of forced displacements. Some of her recent work includes: "Deslocamento forçado na Colômbia e Políticas de refúgio no Brasil: Gestão de populações em êxodo" (Revista de Estudos e Pesquisas Sobre as Américas, 2019), Êxodos, refúgios e exílios: Colombianos no Sul e Sudeste do Brasil (Ed. Papeis Selvagens, 2017). 
Sidney Chalhoub, you were a professor at the University of Campinas (Unicamp - Universidade Estadual de Campinas) until 2015, when you obtained a position at Harvard. Unicamp was or would be one of the most affected universities because the governor of the region is pro-Bolsonaro. Marine Corde, you have studied and worked in three Brazilian federal universities and conducted anthropological research in the country. Angela Facundo Navia, you have made the most of your academic carrier between Brazil, Colombia and France, and you are a close observer of Brazil's sociopolitical life. Can you introduce yourselves and explain the various types of institutional situations (at the local and federal levels)?

Sidney Chalhoub: I taught at the University of Campinas from 1985 to 2015. I am a social historian of Brazil, having done research on the history of working-class culture, slavery, race, and public health. The University of Campinas is a public university in the state of São Paulo funded by taxpayers' money. Students pay no tuition for undergraduate or graduate studies. It is regularly listed among the two or three best universities in Brazil and in Latin America.

Since the funding of state universities in São Paulo depends directly on sales taxes (a fixed percentage of what the state treasury collects is transferred to the universities), they have suffered in the past few years as a result of the economic crisis. Nonetheless, the situation there seems less precarious than in federal public universities because the latter are funded by the Ministry of Education and their budgets are decided annually by the government. Thus, a government that is openly hostile to higher learning can cause significant damage to the federal university system.

Marine Corde: I am an anthropologist. I studied anthropology in France, at the University of Lyon (Université Lumière Lyon 2), and in Brazil at the Universidade Federal da Paraíba; I completed my doctoral studies at the National Museum/Federal University of Rio de Janeiro (Museu Nacional/Universidade Federal do Rio de Janeiro - UFRJ). I also taught in the Department of Social Sciences at the Federal University of Viçosa (Universidade Federal de Viçosa). I had the opportunity to benefit from a high-quality academic education in Brazil, and I am very concerned about how the Brazilian university system is being threatened by spending cuts.

At the beginning of 2019, the Bolsonaro government attacked some universities, such as the University of Brasilia (Universidade de Brasília - UnB), the Federal Fluminense University (Universidade Federal Fluminense - UFF), the Federal University of Bahia (Universidade Federal da Bahia - UFBA), and the Federal University of Juiz de Fora (Universdade Federal de Juiz de Fora -UFJF). The Education Ministry (Ministério da Educação-MEC) declared that it would cut the budget of these universities on the pretext that they were not achieving sufficiently good academic results and that they were making too much fuss ("balbúrdia"). The real target was, rather, the good academic work done in those universities that take their social responsibility in Brazilian society seriously. Regardless of the region in which each one is located, I think these universities were especially targeted because they are well-known as critical thought education venues. A few weeks later, the announcement of the spending cuts was extended to all Brazilian federal universities.

Angela Facundo Navia: I obtained my doctorate degree at the Federal University of Rio de Janeiro. I completed a postdoctoral fellowship at the Casa de Rui Barbosa Foundation, also in Rio de Janeiro, and was then hired as a professor in the Department of Anthropology at the Federal University of Rio Grande del Norte (Universidade Federal do Rio Grande do Norte - UFRN), in the northeast region of Brazil. These three institutions, as has happened with the entire education system in Brazil, have suffered different types of attacks in recent years. However, the characteristics, intensity and severity of the problems are very different. The tragedy of the fire at the National Museum in 2018 and its bad management by the government is, without a doubt, the most serious one and most explicitly demonstrated the government's neglect and disinterest in the production of knowledge and the various research and the other activities that were carried out in the institution. A very important heritage was lost regarding the history of Brazil, which was central to the institution's relations and work with indigenous communities, popular favela organizations, religious communities, schools, etc. The continuity of its academic life and graduate programs was also affected, which, in addition to losing materials that constituted the basis of research, still have no definitive and appropriate place to function.

The Fundação Casa de Rui Barbosa suffered more recent attacks, when in October 2019—in spite of the opinion of its researchers, who had proposed a candidate-the journalist and soap opera writer Letícia Dornelles was appointed President of the foundation by the Brazilian government. In addition to not meeting the qualification requirements to occupy the position, she removed several heads of the research centers from their duties in January 2020. The researchers of the foundation - which is reputed for its vast production of knowledge in the fields of law, 
philology, history, literature and cultural policy—strive, however, to maintain the quality of research and the institution standards.

The graduate program in social anthropology at the Federal University of Rio Grande do Norte is a result of the expansion and investment in higher education made during the first decades of the 21st century and has gained a prominent place in the region. Before this expansion movement, graduate programs were concentrated in the south and southeast regions of Brazil. The north and northeast regions, commonly represented in the social imagination as backward regions, were investigated as research subjects but not recognized—or were under recognized-like the researchers themselves. Despite the rapid growth and strengthening of programs in these regions, the hierarchical geopolitics in Brazil puts us in a weaker position compared to the consolidated programs of richer regions. If the more recent north and northeast programs close, anthropology and other disciplines in the human and social areas will again become remote options for many students.

The Minister of Higher Education has brutally decided to stop funding philosophy and sociology in Brazilian universities, disciplines that President Bolsonaro does not consider "useful". This decision was ruthless but ultimately predictable regarding the political direction taken by the Brazilian government. What is the relationship between politics and the human and social sciences in Brazil? This decision seems to be ideological above all. How was it previously under Luiz Inácio Lula and Dilma Rousseff(Workers' Party, Partido dos Trabalhadores - PT)?

Sidney Chalhoub: So far, there has been a big difference between the fiery rhetoric of the government and its Ministry of Education and the actual actions put in place against the universities. To be sure, thousands of scholarships and fellowships have been slashed, and there has been a 30\% cut in the budgets of all public universities under the federal government. However, because it would be unconstitutional, the financial cuts did not include salaries (thus, rigorously, the cuts are a lot lower than they seem at first sight) and it remains illegal to fire professors and even some categories of staff (those who were formally public employees enjoy job security). Therefore, the ideological warfare against the universities, the humanities and social sciences included, is pretty much a lot of noise with little action; the 1988 Brazilian constitution also guarantees the autonomy of public universities in regard to their research and teaching. The government is not allowed to say what is taught or researched in these institutions or determine how much funding will be allocated to the various areas of study.

Marine Corde: As Sidney Chalhoub explains, there are many announcements that "make a buzz", but without any concrete application. It is in the vein of a populist government. The federal government (through the MEC) releases funds for federal universities, but it does not have the authority to decide in which department these funds will be invested. It is up to the universities to decide via their scientific, administrative, and financial management autonomy, which is protected by the Constitution. Unfortunately, budget cuts do not only affect humanities and social science curricula but universities as a whole.

Nevertheless, humanities and social sciences are still pointed out as useless disciplines. It is a deeply rooted social representation, and this is more or less strongly reflected in the political views of governments. There is a revealing anecdote about the relationship between Brazilian governments and human sciences; Brazil has already elected a President who was a highly recognized sociologist (Fernando Henrique Cardoso - 1995-2003), and there is a rumor that Fernando Henrique Cardoso said "forget everything I have ever written" once he became President. As for the PT governments, there have been no ideological attacks on the human sciences. Nevertheless, they have set up programs such as Ciência Sem Fronteiras ("Science without Borders", an international university exchange program that ended in 2017) that have had major impact but were only aimed at students of the so-called exact sciences. These disciplines were perceived as the most appropriate to maintain the competitiveness of Brazilian universities in the global innovation scene. Even when human sciences are not the target of ideological attacks, they are rarely at the top of the list of scientific areas worthy of major funding. This lack of investment can have dramatic consequences, such as the fire that destroyed the Museu Nacional de Rio de Janeiro in September 2018. The Museu Nacional wasand still is-a reference institute for Brazilian anthropology, research on the history of the country, and the development of public policy for Amerindian peoples.

Angela Facundo Navia: I agree with Marine Corde when she states that even in the days when there were no attack against the social and human sciences, they did not occupy a prominent place either in the hierarchy of professions or in government investment. However, many students from popular sectors benefited enormously from the expansion and internalization policies of universities and federal institutes that were promoted by the governments of Luis Inácio Lula da Silva. Students from rural or hinterland areas, especially from the north and 
northeast regions of Brazil, who previously could not dream of reaching university studies, began to have more and more opportunities to do so. It is not a surprise that the university programs that they attended the most were those that were less competitive and less expensive: social sciences, history, social service, etc. I believe many teachers were trained in this way, and later became active in the basic and secondary education network. As an effectperhaps not planned-it seems, to me, there was a strengthening of critical political thinking that those students and teachers contributed to promote.

The transformation of the situation, with the attacks from the Bolsonaro government, directly affects this panorama. Next to dismantling the teaching of sociology and history in primary and secondary schools, these attacks also go against the interests of the students in the university curricula, which, in addition to not being prestigious, cease to offer the most obvious employment opportunity in an increasingly unequal society that lacks job opportunities for them. At the graduate level, the strongest attack has come, on the one hand, with the cut of scholarships for master and doctoral students that clearly affect the quality of research and survival possibilities for students and, on the other hand, with the freezing of expenses that prevents us from hiring new teachers at the university. But I am suspicious that the upcoming ultra-neoliberal plan of Paulo Guedes (the Minister of Economy of the Bolsonaro government) is even worse, judging by the purposes of his sister, Elizabeth Guedes, who is vice President of the National Association of Private Universities (Associação Nacional das Universidades Particulares - Anup) and known for defending the interests of private educational monopolies.

What can you tell us about the question of the "return on investment" of science in Brazil (i.e., about Bolsonaro's declaration: "O objetivo é focar em áreas que gerem retorno imediato ao contribuinte" ("The objective is to focus on areas that generate immediate returns to the taxpayer")? Is this a long-standing debate, and of which socio-political processes is this statement more broadly indicative?

Sidney Chalhoub: Public universities in Brazil (federal and state universities included) are responsible for $95 \%$ of all scientific research done in the country in all areas. Harming them means literally working against all scientific research and technological progress and innovation done there. Furthermore, because of a great expansion of the system and the adoption of strong affirmative action policies in admissions in the past fifteen years or so, public universities are now very diverse in their composition (regarding the student body, not the professorate). The last data available show that the percentage of students of African descent in public universities is now close to the overall percentage of people of African descent in the Brazilian population (about $53.6 \%$ of the population is of African descent, making Brazil the second "African" nation on the planet, behind Nigeria only). These facts mean that the university system is deeply rooted in Brazilian society—it is the most efficient means for social mobility available to the low and middle economic sectors of the population. Bolsonaro's threats have been met with hundreds of thousands of students and professors marching in the streets on May 15 and May 30, 2019; they joined a national strike on June 14. The government has toned down its bellicose rhetoric since then. Some of the cuts have been reversed, but thousands of scholarships have been lost.

Marine Corde: Attacks on the humanities and social sciences based on the economic arguments of "return on investment" are not the prerogative of the socio-political sphere and the government. They are also widespread in society, being based on a system of representations that ranks the scientific fields (the natural sciences at the top and human sciences and the arts at the bottom of the pyramid). This system of representation is far from recent and is not an exclusive feature of Brazil. However, the speeches against human sciences that result from these representations have gained in scope and salience in the past few years. They have been used (in a radicalized form) in all campaigns against social movements driven by the education sector (secondary and/or higher education) since 2015. I especially think of the occupations of middle and high schools by students protesting the restructuring of the school system in many Brazilian states. I also think of the mobilization of Brazilian university students against the freezing of public spending that was about to affect education. It was not uncommon to hear opponents of these strikes (e.g., political movements, parents' associations, or journalists) arguing that this was the fault of sociology teachers "brainwashing" students with Marxism and radical left ideologies. This was not necessarily the main focus of these opposition movements' discourse, but in the background, these conspiracy theories and misinformation campaigns directly targeted human sciences, which were pointed out as useless or even harmful to society.

With regard to the Bolsonaro government, in practice, the "return on investment" rhetoric has proven to be meaningless. The attacks on all public universities, including those with international reputations, made it clear.

${ }^{1}$ https://twitter.com/jairbolsonaro/status/1121713534402990081 
Spending cuts have affected not only our "useless" disciplines but also socially valued scientific fields such as medicine and civil engineering. Research on the dengue vaccine, cancer, or dam construction (after the tragedies of Mariana and Brumadinho) are also at risk, and nobody can deny these offer a high return on investment. So we can see that the "return on investment" is not necessarily the real issue for the government.

Angela Facundo Navia: Unfortunately, the President and his Minister of Education, Abraham Weintraub, continue to attack the social and human sciences. Recently, in the midst of the COVID-19 epidemic crisis, the Minister of Education tweeted: "I accuse the left of prioritizing schools of anthropology or philosophy, rather than medicine or nursing. I accuse the left of building overbilled stadiums, instead of hospitals. I already said it a year ago. Now, there will be a lack of beds in hospitals, doctors, nurses..." After that affirmation, once again, the President announced that he was going to reduce the budget dedicated to the human sciences.

Disregarding the pathetic and banal use the Minister made of the figure of speech "I accuse" of Émile Zola (perhaps he doesn't even know it), it seems important to me to emphasize that it is not entirely accurate that the current government is withdrawing money from the human sciences to distribute it in the areas that they consider a priority. For example, with the latest CAPES (Coordenação de Aperfeiçoamento de Pessoal de Nivel Superior) resolution of March 18, scholarships were cut from university programs that, even in the government's business logic, would be priority. This was the case of the electrical engineering program of UNICAMP, one of the best-ranked universities in Brazil, just to cite an example among many others. In other words, there is a clear attack on the humanities that, in fact, was recently translated into its exclusion from the national policy of research promotion defined in the resolution No. 1'122 of March 19, 2020. However, the disinvestment is widespread. There are scholarship cuts that affect other areas, and this is not simply a redistribution of resources, but rather gradual and general cuts to free public education, although directed more emphatically and quickly to dismantling the human sciences.

Nevertheless, although the budget cuts do not only affect the human sciences, the discursive attacks are directly addressed against them. As Marine Corde said, not only does the government consider history, sociology or anthropology to be useless, but a good part of society also aligns with that thought and is enraged when, in times of epidemic, they are offered a guilty figure who allegedly takes money that could be "saving lives." It seems to me that, in a fundamentalist religious and anti-intellectual governmental project, the existence of critical sciences that denaturalize the social world and question the religious principles that give a rationale to the domination of some groups over others is extremely uncomfortable. Thus, I believe the attacks will continue, materially and symbolically.

\section{This is not the first attack against universities and the wider intellectual world by a very hard right-wing in Brazil. What historical context is Bolsonarism part of?}

Sidney Chalhoub: Yes, of course, Brazil is part of a global trend. It belongs to a wave of right-wing extremism spanning the globe, from Narendra Modi's India to Donald Trump's USA, and almost everything else in the middle, from Russia, Turkey and Hungary to Italy and Great Britain, and so on and so forth. It is awful. Neoliberal capitalism left us with the predicament of struggling for civilization itself. Universities are very important in this context. In some places, like Turkey, for example, it seems that the government was able to inflict damage quickly and violently, appearing to shut down dissent for a while. It is hard to know what is going to happen in Brazil. In many ways, the destiny of the public universities is the litmus test of Brazilian democracy, of its resilience. Because these institutions are so strong and socially inclusive, so rooted nationally and connected internationally, and because they enjoy significant constitutional guarantees, they are likely to become-perhaps already are-one of the strongholds of resistance against the neofascist tendencies of Bolsonaro's government. If the universities hold on, democracy in Brazil does too. Otherwise, please pray for us.

Marine Corde: In fact, Bolsonarism is far from being a phenomenon unique to Brazil. The neoliberal era has generated many frustrations with the concentration of private power and socio-economic policies that challenge social achievements. Democratic spaces for participation and decision-making are being fragmented. These frustrations have provided fertile ground for hard right-wing populisms, which have supported the anti-system discourse in the countries cited by Sidney Chalhoub (and the list can be completed with France, Spain, Argentina...).

The Brazilian hard right is also embedded in a unique historical context that gives it its reactionary character. First and foremost, it was shaped by the colonial past. It comes from a political and economic colonial elite wellanalyzed by the famous anthropologist Darcy Ribeiro. In his book O Povo Brasileiro, Darcy Ribeiro explains how this elite projected Brazil as an import-export land more than a (national) society based on the—even illusory—values 
of equality, integration, and fraternity. Secondly, the Brazilian hard right is the result of a military dictatorship (1964-1985). Processing the memories of this recent history and the recognition of the violence they entail is still very difficult today. This leads, among other things, the Brazilian hard right to adopt discourses reminiscent of those of the Cold War era in which communism is presented as an imminent threat to Brazil. These discourses have a strong impact in many spheres of Brazilian society.

Since the military dictatorship, public universities in general and human sciences in particular have been among the privileged targets of this hard right; all of this because they produce critical thoughts that support progressive public policies. As stated before, Brazilian universities take their social responsibility very seriously. They are heavily involved in policies related to the rights of indigenous peoples and of quilombolas, and they promote affirmative action, seeking to redress the serious inequalities that characterize Brazilian society. This displeases the reactionary hard right. This is as true for Brazil as it is for other countries in the world. The same attacks against humanities and social sciences are being made in French universities, for example.

Angela Facundo Navia: I fully agree with Sidney Chalhoub and Marine Corde that the phenomenon of economic and financial neoliberalism, accompanied by ultra-moral conservatism, is not just a Brazilian manifestation. On the contrary, we witnessed with horror the rise of this dangerous mixture in various countries of the world. In the Brazilian case, I am also concerned about the similarities that I find with the paramilitary policy regime that have been installed in Colombia since the beginning of the century. Several phenomena seem horrifyingly familiar to me: the emergence of armies of muscular men ready to defend their government's project with blood and fire; the intensified persecution of social leaders, including the assassination of Marielle Franco ${ }^{2}$; the strengthening of armed groups expelling indigenous people, quilombolas ${ }^{3}$, and traditional communities of their lands; the murder and persecution of people with non-hegemonic sexualities or in gender transition; and the pardon granted to large companies that have annihilated entire populations and kill rivers and other ecosystems, such as the Vale case ${ }^{4}$, among other atrocities. I think that, in addition to the relevant mention of the country's colonial past made by Marine Corde, it would be interesting to consult the works produced on the development of the militias of Rio de Janeiro ${ }^{5}$, from the time of the dictatorship to the present day, to understand better the historical context of the emergence of the phenomenon.

\section{Many international mobilizations are underway (seminars, petitions, support, etc.); what about Brazil? Large demonstrations have been organized. What can we expect next? Can we expect a reversal of the government as was the case in Japan?}

Marine Corde: The current Brazilian social and political context is extremely complex. It is characterized by several problems with institutional instability that have intensified with the coup against the former President, Rousseff. Moreover, if Bolsonaro was to be overthrown by an impeachment, it would be Vice President Antônio Hamilton Mourão who would take over the executive. He is a retired general who raised the possibility of military intervention during the crisis caused by the coup against Dilma Rousseff. If Mourão were to be overthrown too, then direct elections (for a dismissal of Mourão before the end of 2020) or indirect elections (from 2021) would have to be organized. In this case, Congress would have to choose the new President, but Congress is strongly marked by the presence of the right and extreme right. There is nothing to look forward to on this side.

However, demonstrations against spending cuts and against attacks on Brazilian public universities continue. I want to remain positive in the face of this very disturbed and disturbing socio-political context. When I taught at the Universidade Federal de Viçosa, many of my students came from very modest backgrounds and were the first in their families to access higher education. Some of them were black students who benefited from affirmative action. Their presence was a sign of significant changes in the academic sphere, and the idea that all this should be compromised by the Bolsonaro government is intolerable. But these students—of social sciences and other curricula-

\footnotetext{
${ }^{2}$ Marielle Franco was a PSOL politician and a LGBT activist who was executed in 2018. Two former members of the Rio de Janeiro military police were blamed for the murder, but the masterminds remain unidentified.

${ }^{3}$ Afro-Brazilian residents of quilombo settlements first established by escaped slaves in Brazil.

${ }^{4}$ The Vale Company is responsible of two of the worst industrial tragedies in the history of Brazil for dam collapses, the first one in 2015 in Mariana-Minas Gerais and the second one in 2019 in Brumadinho-Minas Gerais. In both cases, the mud flooded an inhabited valley, killed hundreds of people, and destroyed ecosystems around.

${ }^{5}$ In a nutshell, militias are criminal organizations made up of retired military, ex-military police or firefighters who, along with civilians, politicians, and active military police, manage various types of illegal businesses on the urban fringes, exercising strong control over everyday life.
} 
continue to develop very rich projects for the university and society. The Brazilian academic world is very committed, and many debates and events are organized to cope with this difficult situation. But it also needs international mobilization to support this fight against attacks on democracy that go far beyond Brazil's borders.

Angela Facundo Navia: Unfortunately, there were no major mobilizations of teachers, students, and other education officials in the past few years. Some marches were massive, but they did not have the same strength, magnitude, and permanence than other demonstrations that became a political force with negotiation or transformation capacity in other countries in Latin America.

On the other hand, scientific associations (Associação Brasileira de Antropologia, Association Nacional de Pos-Graduacao e Pesquisa em Ciencias Sociais, Sociedade Brasileira para o Progresso da Ciência, Associação nacional dos professores universitários de história, etc.) have played the important role of monitoring, mapping and denying false government accusations. More importantly, they overtook the task of reacting quickly against concrete government measures in the fields of science and technology, land and resources, migration, sexual and reproductive rights, education, human rights, native and traditional populations, heritage, culture, religion, etc. Without this active vigilance and political alliances with ad hoc inter-party coalitions around specific issues ("Bancadas"), the situation would be even worse. This task is very exhausting and requires permanent efforts, not only because the measures are frequently introduced without discussion and behind a smoke screen, but also because the government has used the strategy of announcing with great publicity some extreme measures to reduce rights or to attack social achievements in different areas. The government then backs down quickly in its decisions, preventing the constitution of any basis for protests. At the same time, the government advances other measures, less extreme but equally disastrous in terms of rights. To me, it seems possible that Bolsonaro might be ultimately deposed by the same political game that helped him win the presidency. However, the neoliberal project that he accelerated and the fundamentalism that he contributed to launch as a state project will undoubtedly be much more difficult to dismantle and will last much longer than the government.

Until now, in addition to the work of these associations, the international support of intellectuals, universities and other institutions of art, education, and culture has been essential. Unfortunately, I do not know if, in these critical times of COVID-19 pandemic, we will have as many eyes to accompany what happens in the daily life of other countries. 